University of Michigan Law School

University of Michigan Law School Scholarship Repository

Law \& Economics Working Papers

$1-1-2015$

\title{
Encouraging Insurers to Regulate: The Role (If Any) for Tort Law
}

Kyle D. Logue

University of Michigan, klogue@umich.edu

Follow this and additional works at: https://repository.law.umich.edu/law_econ_current

Part of the Torts Commons

\section{Working Paper Citation}

Logue, Kyle D., "Encouraging Insurers to Regulate: The Role (If Any) for Tort Law" (2015). Law \& Economics Working Papers. 112.

https://repository.law.umich.edu/law_econ_current/112

This Article is brought to you for free and open access by University of Michigan Law School Scholarship Repository. It has been accepted for inclusion in Law \& Economics Working Papers by an authorized administrator of University of Michigan Law School Scholarship Repository. For more information, please contact mlaw.repository@umich.edu. 


\title{
Encouraging Insurers to Regulate: The Role (If Any) for Tort Law
}

\author{
Kyle D. Logue \\ University of Michigan Law School
}

\begin{abstract}
Insurance companies are financially responsible for a substantial portion of the losses associated with risky activities in the economy. The more insurers can lower the risks posed by their insureds, the more competitively they can price their policies, and the more customers they can attract. Thus, competition forces insurers to be private regulators of risk. To that end, insurers deploy a range of techniques to encourage their insureds to reduce the risks of their insured activities, from charging experience-rated premiums to giving special premium discounts to insureds who make specific behavioral changes designed to reduce risk. Somewhat paradoxically, however, tort law discourages insurers from engaging in the direct regulation of their insureds' behavior. Under longstanding tort principles, if an insurer "undertakes" to provide serious riskreduction services to an insured, the insurer can be found to have a duty of reasonable care and, should that duty be breached, held liable for any harms caused to third parties. This application of tort principles to insurance companies could be contributing to the moral hazard problem often associated with insurance - the tendency of insurance to cause risk to increase rather than decrease. This Article explores this problem and analyzes a number of ways to encourage insurers to regulate-from insurer-specific Good Samaritan statutes (which we might call a "carrot") to the expansion of tort principles to create an affirmative duty on the part of insurers to regulate (which would definitely be a "stick"). What combination of carrots and sticks produces the optimal insurer incentives to regulate their insureds' behavior? That is the question the Article addresses.
\end{abstract}




\title{
Encouraging Insurers to Regulate: The Role (If Any) for Tort Law
}

\author{
Kyle D. Logue
}

\section{Introduction}

It is well known that insurance companies are financial intermediaries that transfer and spread risk. Specifically, insurers enter into contractual arrangements with risk-averse individuals and corporations in which a broad range of hazards, or sometimes a specific set of hazards, is shifted from the latter to the former. The insurers, who themselves are corporations owned by private shareholders, spread this risk across their policyholders through premiums that reflect average policyholder risk. Thus, each policyholder pays a relatively small and certain premium to the pool in exchange for shifting the risk of a large loss to the pool. The risk-transferring and risk-spreading functions compose the standard picture of insurance markets.

But insurers do more than this. Insurance companies also serve as active risk regulators. ${ }^{1}$ In many of the same ways that government agencies monitor and place limits on the risky behavior of individuals and businesses within their jurisdictions, insurance companies also monitor and place limits on the risky behavior of the people and firms whom they insure. In fact, because insurance is a practical if not a legal requirement with respect to some activities, insurers for those activities function as gatekeepers, determining who gets to engage in the risky activity and who does not. Homeownership, for example, is not possible for most people without home-mortgage financing, which in turn is not available to anyone who does not first purchase homeowners' insurance. Similarly, one cannot legally drive a car in most states without first purchasing the statutory minimum amount of liability insurance. It is also difficult if not impossible to be actively engaged in a profession-law, medicine, engineering, whatever - if one does not have professional liability insurance coverage, purchased either individually or through one's employer.

In addition to keeping the gate to much commercial activity, insurers, like government regulators, also have more subtle regulatory tools. For example, auto insurers charge higher premiums for vehicles that pose a statistically greater chance of being involved in an accident or that are more expensive to repair or more likely to cause harm to others if an accident occurs.

\footnotetext{
* Wade H. and Dores M. McCree Collegiate Professor of Law, University of Michigan Law School.

${ }^{1}$ See generally Omri Ben-Shahar \& Kyle D. Logue, Outsourcing Regulation: How Insurance Reduces Moral Hazard, 111 MICH. L. REV. 197 (2012)
} 
Such risk-differentiated premiums create incentives at the margin for auto purchasers to take into account the risks associated with their vehicle choices. Likewise, when auto insurance companies adjust premiums based on the accident experience of individual drivers or alter rates based on the way in which drivers operate their vehicles or based on the numbers of miles the insured drives, the insurer is in effect regulating driver behavior--forcing drivers to internalize the expected value of the accident-costs associated with her driving choices. In this way, auto insurance premiums - all insurance premiums - can be viewed as cost-internalizing Pigouvian taxes, similar to taxes on carbon emissions, only here administered by private insurance companies rather than by a government agency.

An argument can be made that this is all to the good. We should want insurers to act as risk regulators. Sometimes regulation is needed, whether because of externalities or cognitive biases or some other market failure. Moreover, there are times when private regulation through insurance can be superior to government regulation. This happens when insurers are able to take advantage of their two primary institutional advantages over government regulators: First, private insurers have relatively cheap access to highly relevant risk-related information; second, private insurers are motivated by profit to find clever and practical ways to reduce risks. These two factors explain not only why regulation by insurance is often desirable, but also why it is common.

There is one type of regulation by insurers, however, that is surprisingly uncommon. It is analogous to what the literature on government regulation might call "direct regulation" or "input regulation" or "commandand-control regulation." For example, when the EPA inspects a coal-fired power plant and issues an order specifying steps that the operator of the plant must take to minimize harmful emissions into the atmosphere, such an intervention is a quintessential example of direct regulation. Direct regulation is generally considered the policy instrument of choice only if the regulator has vast quantities of information regarding the regulated risk. Insurers, because of their access to information regarding insured risks, are uniquely suited to engage in direct regulation. Insurers, for example, could inspect their insureds' activities and recommend specific steps that the insureds should take to reduce the risks that they pose to themselves and to others. Moreover, insurers could give those recommendations teeth by linking them to premium adjustments or by making them a condition of coverage.

Although insurers do engage in some direct regulation (as discussed in more detail below), they do surprisingly little of it, given the potential benefits. And the reason for this, or one potential reason for it, is surprising as well: Insurers' incentive to engage in direct regulation of their insureds' risky behavior may be inhibited by a concern about potential tort liability. Under well accepted common law principles of tort, if a party undertakes to render a service that is expected to reduce the risk of harm to a third party, then the party providing the service has a duty to take reasonable care in engaging in this undertaking. ${ }^{2}$ Some states have enacted statutes that eliminate this duty as it applies to insurance companies, or as it applies to a subset of insurance

\footnotetext{
${ }^{2}$ Restatement (Third) Torts: Liability for Physical and Emotional Harm $\S 42$. The Third Restatement is a revision of the language from the Restatement (Second) Torts $\S$ 324A.
} 
companies such as workers' compensation insurers. Most states, however, have no such "insurer Good Samaritan laws," but have instead left in place the common law cause of action, sometimes referred to as the tort of "negligent inspection." What's more, in most of those states, the doctrine of negligent inspection has in fact been applied to insurance companies. Therefore, existing tort doctrine in most states does in fact pose a risk to insurers who engage in direct regulation of their insureds: if they regulate poorly, they may be held responsible for the consequences.

Whether or not exposing insurers to such tort liability is a good thing depends on tradeoffs that are familiar to the economic analyst of law. On the one hand, it can be argued that applying the negligent inspection rule to insurers has at least two potentially negative effects: insurers are discouraged from engaging in socially desirable regulation of risk; and insurers who do engage in such regulation find it necessary to raise their premiums to cover the additional tort risk to themselves, thereby pricing some insureds out of the market for coverage. If these to effects are large, perhaps more states should enact insurer Good Samaritan laws. On the other hand, it can also be argued that applying the negligent inspection rule to insurers enhances efficient deterrence by encouraging those insurers who undertake to provide safety inspections the incentive to do so in a reasonable way, an incentive that the market alone does not provide (for reasons to be discussed further below). If that is so, perhaps the existing insurer Good Samaritan statutes should be repealed.

Of course, enactment or repeal of insurer Good Samaritan statutes are not the only two options. There are both more extreme and less extreme alternatives. For example, if it is the case that insurers are in the best position to prevent certain accidents from happening - if insurers are the "cheapest cost avoiders"-it is conceivable that courts or legislatures could create an affirmative duty on the part of insurers to regulate - to provide specific safety recommendations or mandates when doing so would constitute reasonable care. Such a rule could be seen as a major expansion of traditional tort law, which generally imposes no affirmative "duty to rescue" others who are in danger, not even when doing so would impose little risk to the rescuer. Alternatively, a duty imposed on insurers to regulate could instead be seen as a hybrid of the existing exception to the no-duty-to-rescue rule, specifically, the exception for situations in which the tort defendant has a "special relationship" with the victim.

This Article explores all of these possibilities. Part II provides a more detailed discussion of why insurers might be viewed as effective private regulators of the risks posed by their insureds. Part III surveys the existing doctrine dealing with negligent inspection liability, as applied both to trade associations and insurance companies - both examples of private risk regulators. Part IV addresses the normative questions: how would insurers respond to various alternative tort rules with respect to direct regulation by insurers of their insureds and what rule or combination of rules would create the optimal incentive structure. This Article builds on a number of literatures, including the previous work on trade-association and insurer liability for 
negligent standard setting and negligent inspections ${ }^{3}$ as well as the literatures on vicarious and gatekeeper liability ${ }^{4}$ and the duty to rescue. ${ }^{5}$

\section{Insurers as Private Regulators}

Economic theories of regulation seek to identify the situations in which market failures give rise to the need for government intervention in the economy and what sort of interventions make the most sense, whether it be command-and-control regulations, performance standards, cost-internalizing taxes, or some combination. ${ }^{6}$ Whatever regulatory intervention is chosen, effective regulation requires that the regulatory decisionmaker have enormous amounts of information about the behavior of the regulated parties and about the consequences of that behavior. After all, the regulator must identify the optimal standards of conduct and the appropriate penalties for breaching those standards, both of which are information-intensive inquiries. This is why economic theories of rulemaking focus on the comparative abilities of different regulatory institutions -courts as compared with agencies, for example- to gather and process risk-relevant information. ${ }^{7}$

Effective regulation also requires proper motivation. The regulator must have an incentive to produce and enforce regulations that maximize social welfare. Many, perhaps most, individuals who work for government agencies generally have such an incentive. ${ }^{8}$ That is, however, not always true. In fact, it is almost a cliché to point out that regulatory agencies often have incentives

\footnotetext{
${ }^{3}$ Two important articles on the liability of trade associations are Ralph G. Wellington \& Vance G. Camisa, The Trade Associations and Product Safety Standards: Of Good Samaritans and Liability, 35 WAYNe L. ReV. 37 (1988); and Peter H. Schuck, Tort Liability to Those Injured by Negligent Accreditation Decisions, 57 LAW \& CONTEMP. PROB. 185 (1994). There have been a number of articles written on negligent inspection liability of insurers. James F. Reddoch, Jr., Insurer's Liability for Negligent Performance of Voluntary Safety Inspections 3 CuMB. L. REV. 118 (1972); Michael Braden, An Insurer's Liability to Third Parties for Negligent Inspection, 66 KY. L. J. 919 (1977); Victor Goldberg, Tort Liability for Negligent Inspection by Insurers, in RESEARCH IN LAW AND ECONOMICS: A RESEARCH ANNUAL 76 (Richard O. Zerbe, editor) (1980); Amy Schulman, Recent Developments in Self-Insurance and Risk Management, 32 TORT \& INS. L. J. 479 (1995); John Dwight Ingraham, Liability of Insurers for Negligent Inspection of Insured Premises, 50 DRAKE L. REV. 623 (2002).

${ }^{4}$ See, e.g., Alan O. Sykes, The Economics of Vicarious Liability, 93 YALE L. J. 1231 (1984); and Renier Kraakman, Gatekeepers: The Anatomy of a Third-Party Enforcement Strategy, 2 J. L. E. \& O. 53, 57 (1986).

${ }^{5}$ See, e.g., Landes \& Posner, Salvors, Finders, Good Samaritans, and Other Rescuers: An Economic Study of Altruism, 7 J. Legal STUD. 83 (1978); and Saul Le.vmore, Waiting for Rescue: An Essay on the Evolution and Incentive Structure of the Law of Affirmative Obligations, 72 VA. L. REV. 879 (1986)

${ }^{6}$ E.g., STEPHEN BREYER, REGULATION AND ITS REFORM (1982).

${ }^{7}$ See, e.g., Louis Kaplow, General Characteristics of Rules, in 9 ENCYClOPEDIA OF LAW AND ECONOMICS 510-11 (Boudewijn Bouckaert \& Gerrit De Geest eds., 2000); Steven Shavell, A Model of the Optimal Use of Liability and Safety Regulation, 15 RAND J. ECON. 271 (1984); and Steven Shavell, The Optimal Structure of Law Enforcement, 36 J.L. \& ECON. 255 (1993).

${ }^{8}$ See, e.g., Steven P. CRoley, Regulation and Public Interests: The Possibility OF GOOD REGULATORY GOVERNMENT (2008).
} 
that do not align perfectly with the public interest. ${ }^{9}$ Although the problem can be exaggerated, agency capture continues to be a thing. This is especially true in situations in which the regulated parties are relatively few in number with relatively homogeneous interests and are relatively well off, while the beneficiaries of the regulation are the diffuse public. ${ }^{10}$ In such situations, government agencies can have a tendency to regulate primarily in the interest of the parties they are regulating, which may well conflict with what maximizes overall social welfare. Moreover, even without agency capture, there can be a lack of motivation when agencies are not disciplined by market forces in the way that private firms are.

Many commentators have noted that insurance companies can and do act as regulators of risk. ${ }^{11}$ Building on this scholarship, Omri Ben-Shahar and I have argued that insurance companies in some settings have a comparative advantage over government regulators of risk, having to do with both information and motivation. ${ }^{12}$ The informational advantage that insurers have results from the nature of private insurance markets. Because insurers are providing risk shifting and risk distributing services to their insureds, they need to keep track of risk-relevant data for purposes of pricing. This information is gathered at the underwriting stage (when the insurer must decide whether to insure a particular insured and at what price) and at the claims stage (when the insurer decides whether and how much to pay out for each claim that is filed). Each insurer has its own data that pertains to the pool of insureds that it insures. In addition, the industry gathers and pools information through institutions called insurance "rating bureaus" or "rating agencies."

This is the sort of information that a regulator would obviously find useful. Indeed, such information-about the risks presented by particular

\footnotetext{
${ }^{9}$ See, e.g., Richard A. Posner, Theories of Economic Regulation, 5 BELL J. ECON. 335 (1974).

${ }^{10}$ George J. Stigler, The Theory of Economic Regulation, 2 BELL J. ECON. 3 (1971).

${ }^{11}$ Steven Shavell, On Liability and Insurance, 13 BELL J. ECON. 120, 120-22 (1982) (exploring the relationship between tort law and insurance and how insurance has potential to created optimal accident-prevention incentives); KENNETH S. ABRAHAM, DISTRIBUTING RISK 57 (1986) (coining the term "surrogate regulation" when describing the (then new) regulatory role being foisted on liability insurers to regulate toxic tort and environmental risks); DAVID A. Moss, WhEN ALL ElSE FAILS: GOVERNMENT AS THE Ultimate Risk MANAGER (2002); Tom Baker, Bonded Import Safety Warranties, IN IMPORT SAFETY: REGUlATORY GOVERNANCE IN THE GLOBAL ECONOMY 215 (Cary Coglianese et al. eds., 2009) (arguing for reliance on insurers to police food safety); Jon D. Hanson \& Kyle D. Logue, The First-Party Insurance Externality: An Economic Justification for Enterprise Liability, 76 CORNELL L. REV. 129, 145-53 (1990) (arguing for shifting the regulatory function of product safety to products liability insurers through adoption of strict products liability); Joshua Ronen, Post-Enron Reform: Financial Statement Insurance, and GAAP Re-Visited, 8 STAN. J.L. BUS. \& Fin. 39, 48 60 (2002) (arguing for use of insurance to regulate accuracy of financial statements). For a detailed proposal to privatize the regulation of medical care that raises many of the same arguments that have been raised in support of using private insurers as regulators of risk more generally, see Ronen Avraham, Private Regulation, 34 HARV. J.L. \& PUB. POL'Y 543 (2011).

12 Omri Ben-Shahar \& Kyle D. Logue, Outsourcing Regulation: How Insurance Reduces Moral Hazard, 111 MICH. L. REv. 197 (2012). This Part draws heavily from this Article.
} 
insureds and about the effect on those risks of the insureds' choices and actions - is arguably essential to effective regulation. What's more, such information is costly to collect. Assuming insurers must collect the information in any event, it would be entirely duplicative and wasteful to have government regulators gather all the same information as well. This does not mean that the government should not also gather risk related information. Rather the point is that, for those risks that have a thriving, competitive, individually underwritten insurance market, private insurers will have access to a level of risk-related information that would not be cost justified for the government to collect.

Insurers also invest resources specifically to identify the best ways for insureds to reduce their losses. For example, a group of large property/casualty insurance companies have for many years operated a research institute that tests and rates the crashworthiness of automobiles, producing information that is, or can be, used by consumers in making choices about which cars to buy. ${ }^{13}$ More recently, insurers have begun a similar effort with respect to risks of damage to property, especially damage from disasters. ${ }^{14}$ In both of these cases, the information that is generated is shared with consumers generally and, in some cases, with policy makers. These types of safety research-and-development initiatives are not unique to insurance companies and are sometimes replicated by the government. Nevertheless, they do contribute to the overall stock of information that insurers have, which no other institution can claim.

Insurance companies also have a strong incentive to help their insureds reduce the risks they face, an incentive that government agencies do not have and that is (mostly) consistent with the public interest. Liability insurers are obviously on the hook contractually when their insureds negligently cause harm to others. Therefore, the insurer that fails to find the most cost-effective way of reducing the risks posed by its insureds, and thereby reduce its premiums, may find itself losing customers to its more innovative competitors who can offer cost savings. Even absent strong competition among insurers, an insurance company has an incentive to maximize its own profits by minimizing its costs, which means, after the insurer has collected the premiums, finding ways to reduce the expected payouts to insureds.

Besides their unique access to information and their competitive motivation, insurers also have access to a number of especially effective regulatory tools. ${ }^{15}$ For example, deductibles and copayments, insurance contract terms that impose some portion of every loss on insureds rather than on insurers, can be understood as devices to align insureds' accident-prevention incentives with those of their insurers. Similarly, exclusions impose on insureds all of certain types of losses, often losses from particular types of

\footnotetext{
${ }^{13} \mathrm{http}$ ://www.iihs.org/.

14 https://www.disastersafety.org/.

15 Other scholars have pointed this out. See, e.g., Tom Baker \& Thomas O. Farrish, Liability Insurance and the Regulation of Firearms, in SUING THE GUN INDUSTRY 292 (Timothy D. Lytton ed., 2005) (identifying and categorizing the various methods of regulation used by insurers); Victor P. Goldberg, The Devil Made Me Do It: The Corporate Purchase of Insurance, 5 REV. L. \& ECON. 541 (2009) (same); Haitao Yin, Howard Kunreuther \& Matthew White, Risk-Based Pricing and Risk-Reducing Effort: Does the Private Insurance Market Reduce Environmental Accidents?, 54 J. L. \& ECON. 325 (2011) (same).
} 
excluded causes, such as intentional wrongdoing. While the ex post effect of such exclusions can be draconian (i.e., total loss of coverage), the ex ante effect is to strongly incentivize insureds not to engage in certain types of behaviorsuch as intentionally causing the loss.

One of the most powerful regulatory tools wielded by insurers is the insurance premium itself. Profit-maximizing insurers seek to charge premiums equal to the expected costs of the individuals and firms they insure-that is, premium which are differentiated based on the risk presented by each insured. Failure to charged risk-differentiated premiums can result in the loss of lowrisk customers, who will find paying the undifferentiated premiums to be a bad deal. Such low-risk parties may either shift to competing insurers who have more accurately priced policies or, depending on how risk averse the parties are (and how inaccurate the premiums), opt for being self- or uninured. The departure of low-risk insureds from an insurance pool then leads to higher average costs for the remaining pool participants, which can then induce the previously-average-but-now-low-risk insureds in turn to drop out. And so on until, in the worst case (though perhaps unlikely) scenario, the insurance pool "unravels" entirely. ${ }^{16}$ To prevent all of this from happening, insurers attempt to charge premiums that reflect the differences in the risks posed by particular insureds. ${ }^{17}$ And when an insured's risks change over time, so must the insurer's premiums. Such premium adjustments require information, which the insurers gather through experience-rating, based on the loss-experience of particular insureds during the previous insured period, as well as through pre-loss riskrating, based on information about insureds gathered during the initial underwriting or renewal processes.

The efficiency benefit of having risk-differentiated premiums has to do with cost-internalization. That is, to the extent insurance premium differentials reflect risk-related choices made by insureds - so that insureds can, by altering their behavior, reduce or increase their insurance premiums - those premiums operate as a sort of cost-internalizing, Pigouvian tax, not unlike a pollution tax. Insureds, because of the obligation to pay the premiums, are forced to take into account the full social costs of their decisions, which they might otherwise externalize.

Similar cost-internalization can be achieved by insurers with deductibles and copayments. These are contractual provisions that leave the insured responsible for covering some portion of their insured losses. Economists have long known that such cost sharing can be efficient in insurance contracts, precisely because perfectly individualized and riskadjusted insurance premiums are not possible, given the amount of information

\footnotetext{
${ }^{16}$ George L. Priest, The Current Insurance Crisis and Modern Tort law, 96 YALE L. J. 1521 (1987). There is a strong case to be made that this sort of "death spiral" unraveling is rare and unlikely. Peter Siegelman, Adverse Selection in Insurance Markets: An Exaggerated Threat, 113 YALE L. J. 1223 (2004).

${ }^{17}$ Note that this practice of risk-adjusted individualized premiums is consistent with the idea of risk shifting from insured to insured. That is, a risk-averse insured would rather pay an insurance premium that accurately reflects his or her particular risk than to bear the risk itself, assuming they can afford to pay the premium.
} 
that would be required. ${ }^{18}$ A deductible automatically forces the insured to internalize the costs of their activities, up to the amount of the deductible. Thus, an insurance contract that contains a deductible can induce an insured to make particular investments to reduce risks, even when the insurer is not able to monitor the insured's behavior. Deductibles work best for small but highly effective care level investments: for example, when an insured can virtually eliminate a particular risk (and thus the risk of having to pay out it the deductible) by making a minor investment in accident prevention. ${ }^{19}$

In addition to incentive-based regulation through the use of premiums and deductibles and the like, insurers also engage in some forms of direct safety input regulation, similar to what the EPA does when it tells a power plant how specifically to alter its practices to reduce emissions; or what OSHA does when it inspects a workplace and identifies safety improvements that need to be made. Insurers, especially liability insurers-workers' compensation, products liability, commercial property liability - are in a position to do this sort of inspection work reasonably well. As Victor Goldberg once put the point, "a tied sale of insurance cum inspection has very attractive properties. By tying inspection to insurance the parties make the inspector's compensation contingent on upon its success." 20

This regulation by insurer inspection developed first with boiler and machinery first-party coverage (discussed further below), but insurer inspections now are used to some extent with range of types of coverage. Most large property/casualty insurance companies have an office or department whose primary job is to educate insureds about how to reduce risks. These services have a number of different titles: "loss control," 21 "loss prevention,"22 "risk control,", 23 or even "risk engineering.,"

I have just laid out the most optimistic version of the insurance-asregulation story. The truth is more complex, of course, and considerably less

\footnotetext{
${ }^{18}$ Economists have famously noted that deductibles can be used to induce insureds to voluntarily sort into high-risk and low-risk groups, when expressly risk-differentiated premiums is not practical. Thus, under certain assumptions, low-risk insureds would agree to a contract that contains a deductible but relatively low premiums, while highrisk insureds would prefer no deductible with a higher premium. The seminal article showing this result is Michael Rothschild \& Joseph Stiglitz, Equilibrium in Competitive Insurance Markets: An Essay on the Economics of Imperfect Information, 90 Q. J. ECON. 629 (1976).

${ }^{19}$ See, e.g., Ronen Avraham, The Economics of Insurance Law-A Primer, 19 CONN. IN. L. J. 29, 66 (2012)(explaining how deductible can induce insureds to make low-cost risk-reducing changes in behavior).

${ }^{20}$ Victor Goldber, Tort Liability for Negligent Inspection by Insurers, in RESEARCH IN LAW AND ECONOMICS: A RESEARCH ANNUAL 73 (Richard O. Zerbe, editor) (1980).

${ }_{21}$ State Farm: http://www.farmers.com/business/loss-control/; The Hartford: http://www.thehartford.com/loss-control/; Berkshire Hathaway: https://www.bhhc.com/workers-compensation/services/loss-control.aspx.

22 AIG: http://www.aig.com/kw-property-loss-prevention_821_330338.html; and http://www.aig.com/loss-prevention-services_3171_444286.html.

${ }_{23}$ Travelers: https://www.travelers.com/business-insurance/risk-control/index.aspx; Liberty Mutual: http://www.libertymutualgroup.com/business-insurance/insurancenews/risk-management.

${ }^{24}$ Zurich: http://www.zurichna.com/zna/risk_engineering/risk_engineering.htm.
} 
rosy. While insurance companies have some comparative advantage as risk regulators in certain settings, they also have limitations. First, unlike a government agency, an insurance company has no power to compel action under threat of force; insurers have only the threat of premium increases or coverage cancelation or other contractual remedies. Second, those contractual remedies are far from ideal. Although some insurers adjust premiums based on their insureds' risky choices, some do not, or they do so only minimally, because of high information and transaction costs. ${ }^{25}$ Third, to the extent that insurance companies do not get actively involved in the regulation of their insureds, whether through premiums adjustments or mandatory inspections or whatever, insurance can have a counterproductive effect on incentives. Insurance can, and sometimes does, undermine incentives to reduce risk. It is common knowledge that insurance can produce moral hazard; and any attempt to use insurance as a form of regulation must take this possibility into account. ${ }^{26}$ Fourth, with respect to liability insurance in particular, if the insured's activity poses a risk of harm to others that exceeds the value of the insured's assets (in which case the insured is said to be "judgment proof'), insurance cannot perform well as a regulatory mechanism, unless it is accompanied with a coverage mandate. Fifth, and most obvious, the interests of insurance companies - even in reasonably competitive markets - can and do sometimes diverge from the interests of society generally. This is why insurance companies and insurance contracts are themselves regulated. For one example, bad-faith law is necessary to counteract insurers' financial incentive to behave opportunistically with respect to their insureds in situations in which market forces alone are not likely to punish such opportunism. ${ }^{27}$ Another example would be the problem of loss externalization by insurers, through the use of annually renewed contracts. ${ }^{28}$

\footnotetext{
${ }^{25}$ In addition, many premium adjustments have nothing to do with insureds' choices, but rather are based on more or less immutable characteristics. For example, while significant premium discounts for driving fewer miles is likely to have efficient behavioral effects, discouraging unnecessary trips in the car, premium differentials based on age, race, or gender are less likely to have beneficial incentive effects. Rather, they merely have the effect of distributing the costs of such accidents among insureds on the basis of these characteristics.

${ }^{26}$ For the origins of the concept, see KENNETH ARROW, EsSAYS IN THE THEORY OF RISK-BEARING (1971), and Bengt Hölmstrom, Moral Hazard and Observability, 10 BeLl J. ECon. 74 (1979). For its relevance to law, see Kenneth S. Abraham, Distributing Risk (1986), and Tom Baker, On the Genealogy of Moral Hazard, 75 TEX. L. REV. 237 (1996).

${ }^{27}$ For a fuller discussion of the types of insurance regulation and their market-failure rationale, see Baker \& Logue, Insurance Law. In addition, to the extent liability law itself is vague or ambiguous, liability insurance companies and their representativesas translators of that law for their insureds-will have a tendency to encourage their insureds to reduce their legal risk not only by being more careful and thus reducing risk of harm to others (which is social welfare enhancing) but also by changing the way their behavior can be legally characterized and thus reducing liability risk without really reducing risk of harm to others. See, e.g., Shauhin Talesh [article in this volume about EPLI]

${ }^{28}$ Insurance contracts usually last for only one year. As a result, any losses that the insured is likely to sustain in years after the policy has lapsed may be externalized, or ignored, by the current insurer. This effect is limited with occurrence based liability
} 
For all of these reasons, it obviously does not make sense to rely solely on insurers as regulators. For some risks, government regulation is the only option. For others, perhaps there is no regulatory solution. But for some subset of risks, insurers' incentives to minimize their insureds' losses can be a useful supplement to government regulation. Moreover, it is almost inevitable, so long as privately sold, individually underwritten insurance contracts are permitted. That is, so long as there are risk-averse individuals and firms demanding insurance coverage, and so long as there are competitive insurance markets responding to that demand, insurers will have an incentive to reduce their insureds' risk levels and thus they will regulate, subject to the qualifications listed above. The point of this section has been to summarize why this role of insurance should be accepted, perhaps encouraged.

There is a possibility, however, that existing tort law is indeed discouraging insurers from regulating, even when we should want them to. In the process of doing research for another Article, I interviewed a number of officials at large property/casualty insurance companies, and some of them stated that they are reluctant to get too involved in the safety-related decisions of their insureds, because of the concern that by doing so they will expose themselves to tort liability. This factual claim is impossible to verify without access to data that only the insurers have and that they are generally not willing to share with others. The question that can be explored, however, is whether the claim that tort law discourages insurers from regulating is plausible. That is the question taken up in the next Part.

\section{Current Law: The Tort of Negligent Inspection}

As it turns out, there is indeed a well settled doctrine within American tort law that insurers who engage in the active regulation of their insureds' behavior, through inspection or standard setting or whatever, owe a duty of reasonable care to the insureds as well as to any other relying third parties. To understand this rule, however, one must first understand the general no-duty-torescue rule, to which the negligent inspection rule is an exception. The noduty-to-rescue rule itself is very simple to understand: There is no duty, generally, to volunteer to rescue another who is in danger. So, if you come across a person who is drowning, whom you could easily help without taking any risk yourself (maybe you need only toss the person a life preserver or call 911), tort law says that you may simply let the person drown, without lifting a finger or dialing for help. To be sure, if you did that, you would be a jerk, and at least one jurisdiction within the U.S. might fine her $\$ 100$ for such an egregious nonfeasance. ${ }^{29}$ But you would not be a tortfeasor in the eyes of the U.S. common law. ${ }^{30}$

This general rule has several well-known exceptions. For starters, if one party's actions put another at risk of harm, the first party may have a tortbased obligation to provide assistance to the second, assuming the first person was aware or should have been aware of her role in creating the risk. In

insurance, which puts the insurer on the hook for any current or future claim arising out of "occurrences" that take place during the policy period. But even there, the insurer will tend to externalize post-policy occurrences.

${ }^{29}$ Vermont's Dut to Aid the Endageed Act, Vt. Stat. Ann. Tit. 12, § 519(a).

${ }^{30}$ The rule is different in a number of other countries. 
addition, there are a number of "special relationships" that courts have recognized as creating a duty to take affirmative steps to prevent harm to others. For example, courts have held that a common carrier owes something like a duty to rescue to its passengers, at least while they are in transit. Landowners traditionally owe a similar duty to invitees and licensees on their property. In addition, some courts have even found that special relationships between two parties (A and B) can create a duty in one (A) to prevent the other (B) from harming a third party (C). In such cases, the duty is owed, in sense, by A to C. An example of this involves hospitals: in most jurisdictions, hospitals owe an obligation to take reasonable steps to prevent their patients from harming others. Taking this exception a step further, in the famous Tarasoff decision, the California Supreme Court recognized an affirmative duty on the party of mental health professionals under certain circumstances to prevent their obviously dangerous patients from harming others. ${ }^{31}$ Many other jurisdictions have since adopted this rule as well. Again, these specialrelationship cases, to which we will return later in this Article, are important exceptions to the otherwise generally applicable no-duty-to-rescue rule.

The other (and final) exception to the no-duty-to-rescue rule takes us one step closer to the law governing insurers as regulators. It is the exception for voluntary undertakings. The quintessential example involves a failed rescue attempt. Specifically, if a person voluntarily undertakes to render aid to another who is at risk (the drowning stranger, for example), then the would-be rescuer has a tort duty to exercise reasonable care in attempting the rescue. The rule makes some sense. After all, if one person undertakes to make a rescue, other potential rescuers, seeing the first rescuer, may refrain from volunteering, which could make the rescuee's situation even more perilous. As a result, it isn't crazy that someone who is undertaking to rescue another should be encouraged by tort law to do a reasonably good job of it. (We will have more to say about the wisdom of all of these rules later in the Article.)

The negligent-undertaking rule was eventually extended to situations that include private regulation of risky activities, including private regulation by insurance companies of their insureds' activities. Under this rule, stated generically, if Party A undertakes, for pay or voluntarily, to provide services for Party $\mathrm{B}$, which services are expected to reduce a risk facing Party $\mathrm{C}$, then A owes a tort duty to $\mathrm{C}$ to exercise reasonable care, provided that either $\mathrm{B}$ or $\mathrm{C}$ is relying on $\mathrm{A}^{32}$ This rule was tailor made to regulate private regulators.

Consider first the example of trade associations as standard setters. ${ }^{33}$ Trade associations are nonprofits organized to represent the interests of firms in a particular industry. One important function of a manufacturing trade association is to promulgate product design and safety standards, which are then followed by manufacturers who are members of the trade association. A manufacturer's failure to follow the privately promulgated standard product safety standards can result in tort liability for the manufacturer, as failure to

\footnotetext{
${ }^{31}$ Tarasoff v. The Regents of the University of California, 551 P.2d 334 (Cal. 1976).

${ }^{32}$ Restatement (Third) Torts $\S 43$, with special emphasis on subsection (c). A similar rule is also in section 342A of the Restatement (Second) of Torts.

${ }^{33}$ The leading article on this topic is Ralph G. Wellington \& Vance G. Camisa, The Trade Associations and Product Safety Standards: Of Good Samaritans and Liability, 35 WAYNE L. REV. 37 (1988).
} 
follow industry standards is considered relevant evidence of negligence or defective design. Therefore, such trade-association-promulgated standards can be understood as a form of direct private regulation, similar to the direct private regulation that insurers provide, as described above. ${ }^{34}$

As a result of the negligent-undertaking rule described above, the promulgation of private standards of care can also subject the trade associations to tort liability. For example, in King v. National Spa \& Pool Institute, an industry association set standards governing the type of diving board that can be safely used in with swimming pools of various depths and sizes. The court there held that, because the trade association voluntarily undertook a duty to exercise due care in promulgating safety standards, it had a duty to do so with reasonable care. ${ }^{35}$ There are many other such cases. Trade associations from the chemical industry, the blasting cap industry, the window treatment industry, the welding industry, among many others, have been found by courts to owe a duty of reasonable care to consumers when establishing industry standards of safety. ${ }^{36}$ The same duty has been applied to hospital associations and associations of state school boards and a whole range of other accreditation entities. ${ }^{37}$ Finally, under the auspices of the voluntary undertaking duty, numerous tort suits have been brought (and won) against the Underwriter's Laboratory, the safety research and certification organization that provides safety standards and inspections for a wide range of products, ranging from all types of electronic devices and their component parts (wiring and whatnot) to fire extinguishers, smoke detectors, and other fire protection technologies. ${ }^{38}$

Clearly tort law is being applied to encourage private standard setters to take reasonable care, and to hold them responsible for failing to take reasonable care, in setting private regulatory standards. Tort law is also being applied in much the same way to insurance companies. In fact, my research assistants were able to find 171 reported negligent-inspection cases involving insurance companies, spread over 41 separate jurisdictions. Of those cases, 107 involved workers' compensation insurance, 33 involved some form of property insurance (often boiler-and-machinery or equipment repair insurance), and the remainder involved other types of insurance. The remainder of this Part summarizes these cases, by type.

It is no surprise that the vast majority of negligent-inspection-by-aninsurer cases have to do with workers' compensation coverage, for two reasons. First, anecdotal evidence suggests that workers' compensation insurers are among the most active direct regulators of their insureds' risky activities. Second, workers' compensation remedies are less generous than traditional tort remedies, which means that the injured party in a workers' comp setting is more likely to have losses that have not been compensated by insurance.

\footnotetext{
${ }^{34}$ See generally Ronen Avraham, Private Regulation, 34 HARV. J. L. \& PUB. POL'Y 543 (2011) (making a similar point in the healthcare context, arguing for, among other things, a private-regulatory compliance defense where doctors sued for malpractice are following privately promulgated evidence-based guidelines).

${ }^{35} 570$ So.2d 612 (Ala. 1990), rev'd on other grounds, 578 So.2d 1285 (Ala. 1991).

${ }^{36}$ See generally, Wellingon and Camisa, supra note _ (collecting cites).

${ }^{37}$ Peter H. Schuck, Tort Liability to Those Injured by Negligent Accreditation Decisions, 57 LAW \& CONTEMP. PROB. 185 (1994).

${ }^{38} I d$.
} 
The workers' compensation negligent-inspection cases share a similar, and unsurprising, fact pattern: a worker, or a group of workers, is injured or killed in a workplace accident as a result of an unsafe work-place condition. ${ }^{39}$ In these cases, in addition to the standard workers' compensation claim that is brought against the employer, a lawsuit is brought by the injured victims against the workers' compensation insurer, alleging that, prior to the accident, the insurer had inspected the workplace and, in effect, deemed it reasonably safe and that the employer-insured and the employees relied on this certification. ${ }^{40}$ In some of the cases there is evidence that the insurer had suggested safety enhancements that were in fact made, but in most of the cases, the evidence is unclear on this point, and the facts reveal only that the insurer had not raised objections to the condition of the workplace before the injury. ${ }^{41}$

The key issue in many of the cases is the question of reliance. ${ }^{42}$ The insurer typically argues that the safety inspection was not made "for the benefit" of the employer-insured or for the benefit of the employees of the insured, but rather were exclusively for the benefit of the insurer. Specifically,

\footnotetext{
${ }^{39}$ See, e.g., Love v. Flour Mills of Am., 647 F.2d 1058 (10th Cir. 1981) (grain elevator employees injured by explosion and fire); Adams v. Travelers Ins. Co., 494 So. 2d 401 (Ala. 1986) (employee injured when roller on an inspecting machine snagged); Burns v. State Comp. Ins. Fund, 265 Cal. App. 2d 98, 71 Cal. Rptr. 326 (Cal. Ct. App. 1968) (employee seriously injured at a sawmill that was negligently inspected by state agencies); Mimms v. Travelers Ins. Co., 156 Ga. App. 889 (1981) (employee injured when he fell off a piece of scaffolding from which safety rails had been removed); Jadosh v. Goeringer, 442 Pa. 451, 275 A.2d 58 (1971) (employee's fingers crushed while operating a hydraulic ram of a lug cover press).

${ }^{40}$ See, e.g., Phillips v. Liberty Mut. Ins. Co., 813 F.2d 1173 (11th Cir. 1987) (employee injured by scaffolding on a construction site inspected by employer's insurance company); Bartolotta v. Liberty Mut. Ins. Co., 411 F.2d 115 (2d Cir. 1969) (employees exposed to argon gas after insurance company inspected employer's factory and equipment); Fireman's Fund American Ins. Co. v. Coleman, 394 So. 2d 334 (Ala. 1980) (employees injured when sparks from tool caused an industrial fire after safety inspection undertaken by insurance company); Van Biene v. Era Helicopters, 779 P.2d 315 (Alaska 1989) (employees killed in plane crash after insurance company negligently approved of working conditions allowing pilots to work longer than allowed by FAA regulations); and Nelson v. Union Wire Rope Corp., 31 Ill.2d 69 (1964) (seven employees killed and twelve employees injured when construction platform fell six stories after negligently inspected by insurance company).

${ }^{41}$ See, e.g., Hill v. U.S. Fid. \& Guar. Co., 428 F.2d 112 (5th Cir. 1970) (insurance company recommended that hotel fix hazards, which hotel relied upon to rectify hazards); Patton v. Simone, 626 A.2d 844 (Del. 1992) (insurance carrier supplied company with list of recommended improvements, which company made, that did not include elevator in violation of building codes).

${ }^{42}$ See, e.g., Phillips v. Liberty Mut. Ins. Co., 813 F.2d 1173 (11th Cir. 1987) (whether or not employer relied on insurer's safety inspection is a jury question); Hill, 428 F.2d 112 (insurance company created reliance by indicating they would carry out safety inspections); Kohr v. Johns-Manville Corp., 534 F. Supp. 256 (E.D. Pa. 1982) (insurer can be held liable if inspections had been carried out negligently and then relied upon by employer); Ray v. Transamerica Ins. Co., 46 Mich. App. 647, 208 N.W.2d 610 (1973) (whether or not employee relied on insurer's safety inspections is a jury question); Derosia v. Liberty Mut. Ins. Co., 155 Vt. 178 (1990) (insurer liable where employee relied on them for expertise in safety matters and where inspections are undertaken for benefit of the insured).
} 
the insurer contends that it engaged in safety inspections solely to determine whether to offer the insurance and if so under what terms. ${ }^{43}$ The relevance of this fact, as mentioned above, is that, because the inspection was solely for the benefit of the insurer, no one else was or should have been relying on the inspection. Some courts have found this argument and the evidence in support of it to be persuasive. ${ }^{44}$ Other courts, however, have found that, irrespective of whether the insurer was motivated primarily or even exclusively to minimize its own risk under the policy, if the insured or other third parties in fact relied on the insurer's safety inspections, the insurer owes a duty of reasonable care. ${ }^{45} \mathrm{In}$ all cases, the issue of reliance is crucial.

In some of these workers' compensation cases, the insurer seeks expressly to avoid negligent inspection liability by referring to language in the policy that explicitly disclaims any duty to the insured or to third parties in connection with the insurer's inspections of the insured's property or premises. ${ }^{46}$ This language, which is an obvious reference to the language found in both the Second and Third Restatements of Tort as well as in the negligent undertaking cases, is routinely enforced by some courts, irrespective of whether

${ }^{43}$ See, e.g., Manker v. Zurich Servs. Corp., 556 F. App’x 907 (11th Cir. 2014) (argued inspection only for purposes of underwriting assessment); Heath v. B.J. Hughes, Inc., 431 So. 2d 68 (La. Ct. App. 1983) (argued inspection done for fulfillment of insurance contract, not for benefit of employees); Jansen v. Fid. \& Cas. Co. of New York, 79 N.Y.2d 867, 589 N.E.2d 379 (1992) (argued inspections carried out solely for underwriting process); Schultz v. Mills Mut. Ins. Grp., 474 N.W.2d 522 (S.D. 1991) (argued inspections carried out solely for insurer's benefit).

${ }^{44}$ See, e.g., Manker, 556 F. App'x at 909 (holding insurance company not liable where it "did not undertake to render services to another which it should have recognized as necessary for the protection of a third person or his things"); Heath, 431 So. $2 \mathrm{~d}$ at 69 (holding insurance company not liable where "policy language makes it clear that the inspections were made only in connection with the contract of insurance, and not for the benefit of the plaintiff."); and Jansen, 79 N.Y.2d at 869, 589 N.E.2d at 380 (holding insurance company not liable where "it is apparent that safety inspections were undertaken solely for the defendant's own underwriting purposes").

${ }^{45}$ See, Kohr v. Johns-Mannsville Corp., 534 F. Supp. 256 (E.D. Pa. 1982) ("The completeness and accurateness of the studies which [the company] received from [the inspector] and their degree of reliance thereon are all material issues of fact obstructing summary judgment); Nelson v. Union Wire Rope Corp. 31 Ill. 2d 69, 79-80 (1964) (insurance company promoted safety inspections as benefitting company's clients, which "fully negates any concept that defendant's gratuitous inspections were solely for its own internal purposes").

${ }^{46}$ See, for example, the language from an old USF\&G workers' compensation policy, as quoted in Tomasich v. United States Fidelity and Guaranty Co., 470 So.2d 491 (La. Ct. App. 1985):

The Company and any rating authority having jurisdiction by law shall each be permitted but not obligated to inspect at any reasonable time the work places, operations, machinery and equipment covered by this policy. Neither the right to make inspections nor the making thereof nor any report thereon shall constitute an undertaking on behalf of or for the benefit of the Insured or others, to determine or warrant that such workplaces, operations, machinery or equipment are safe or healthful, or are in compliance with any law, rule or regulation. 
the employer-insured in fact acted in reliance on the insurer's inspections. ${ }^{47}$ Other courts have viewed such terms with more suspicion. Some have enforced such terms only if there was in fact no evidence of reliance by the employer or the third party victim. ${ }^{48}$ Others have refused to enforce them at all, when third-party victims are involved. ${ }^{49}$ A few have declared such terms void as against public policy. ${ }^{50}$

The second most common type of negligent inspection cases brought against insurers, after the workers' compensation insurance cases, are disputes involving various types of property insurance, especially boiler and machinery coverage. ${ }^{51}$ This also is unsurprising, as insurers who offer boiler and machinery coverage heavily advertise their loss control expertise, which enhances the case for reliance. ${ }^{52}$ Boiler and machinery coverage is usually sold in a special policy, separate from and in addition to the more general property policy, by insurance companies that specialize, or have divisions that specialize, in such risks. The coverage is typically first-party only and insures not only damage to the machinery itself but also any resulting business interruption or other lost income. ${ }^{53}$ The triggering event is the "breakdown" of

\footnotetext{
${ }^{47}$ Louisiana, for one example. Id.; see also Leroy v. Hartford Steam Boiler Inspection \& Ins. Co., 695 F. Supp. 1120, 1127 (1988) (court held insurance company not liable, following reasoning of Smith case below); Smith v. Allendale Mut. Ins. Co., 410 Mich. $685,725,303$ N.W.2d 702, 715 (insurance policy disclaimed liability for inspections and court held "[t]he insurer was entirely justified in so limiting its liability."); and Rosenhack v. State, 447 N.Y.S.2d 856, 860, 112 Misc. 2d 967, 971 (Ct. Cl. 1982) (“The facts clearly and unequivocally lead to the conclusion that this contract for insurance and particularly the provision dealing with inspection of the premises exclude claimant.").

${ }^{4}$ See, e.g., Bussey v. Travelers Ins. Co., 643 F.2d 1075, 1076 (5th Cir. 1981) (insurance company not liable because defendant "did not establish the requisite degree of reliance by himself or his employer on the insurer's inspection services."); Stacy v. Aetna Cas. \& Sur. Co., 484 F.2d 289 (5th Cir. 1973) (upholding the policy language where there was no reliance by the insured or injured workman on the inspections made by the insurance company).

${ }^{49}$ See, e.g., Sheridan v. Aetna Cas. \& Sur. Co., 3 Wash. 2d 423, 100 P.2d 1024 (1940); Van Winkle v. Am. Steam Boiler Co., 52 N.J.L. 240, 19 A. 472 (1890).

${ }^{50}$ Deines v. Vermeer Mfg. Co., 752 F. Supp. 989 (D. Kan. 1990); find workers comp case to cite as well.[can't locate a worker's comp case on this issue]

${ }^{51}$ See, e.g., Manker v. Zurich Servs. Corp., 556 F. App'x 907 (11th Cir. 2014); Howell v. Hartford Steam Boiler Inspection \& Ins. Co., 991 F.2d 795 (6th Cir. 1993); Hartford Steam Boiler Inspection \& Ins. Co. v. Pabst Brewing Co., 201 F. 617 (7th Cir. 1912); Indus. Risk Insurers, Inc. v. New Orleans Pub. Serv., Inc., CIV. A. 81-2635, 1990 WL 28182 (E.D. La. Mar. 13, 1990); Mueller v. Daum \& Dewey, Inc., 636 F. Supp. 192 (E.D.N.C. 1986); Blalock v. Syracuse Stamping Co., 584 F. Supp. 454 (E.D. Pa. 1984); Philadelphia Mfrs. Mut. Ins. Co. v. Gulf Forge Co. 555 F. Supp. 519 (S.D. Tex. 1982); A.O. Smith Corp. v. Viking Corp., 79 F.R.D. 91 (E.D. Wis. 1978); Hassan v. Hartford Ins. Grp., 373 F. Supp. 1385 (D. Del. 1974); Huggins v. Standard Fire Ins. Co., 166 Ga. App. 441, 304 S.E.2d 397 (1983); Cleveland v. Am. Motorists Ins. Co., 163 Ga. App. 748, 295 S.E.2d 190 (1982).

$52 \quad$ Example: https://www.travelers.com/business-insurance/specializedindustries/boiler-machinery/risk-control.aspx.

${ }^{53}$ See, e.g., https://www.travelers.com/business-insurance/specialized-industries/boilermachinery/docs/CP6943EMAX21.pdf;
} 
the machine itself, and not some external force, such as fire or wind or water, which would be covered under the standard property policy. Indeed, what has traditionally been called boiler and machinery insurance is now commonly called "equipment breakdown insurance." 54 Damages are typically limited to the cost of repairing or replacing the broken equipment along with associated lost income to the business - similar to business interruption coverage. ${ }^{55}$

The standard fact pattern in a boiler/machine case is straightforward: a boiler or some other large machine found on the insured's business premises explodes and injures one or more individuals, a tenant or some other customer. The injured individuals then bring suit against the insurer that issued the policy covering the equipment in question. The claim itself typically tracks the language of the sections of the Restatement dealing with negligent undertakings, the main issues again being the nature of the service provided by the insurer and whether that service was for the benefit of the insurer or the victims. ${ }^{56}$ Insurers lose as many of these cases as they win.

Some types of insurance have given rise to very few if any negligent inspection lawsuits against insurers, presumably because insurers in those contexts are engaging in relatively little direct regulation-or perhaps because the sort of direct regulation that is being done produces relatively little likelihood of a negligence claim. For example, there are few cases involving homeowners' insurance, and the cases that have been reported involve claims adjusting rather than pre-loss inspections and, in any event, have almost uniformly favored insurers (on reliance grounds). ${ }^{57}$ There are essentially no auto insurance cases. ${ }^{58}$ Neither of these is a surprise, under current law. Homeowners' insurers do not inspect homes and provide certification of safety,

http://www.zurichcanada.com/internet/can/SiteCollectionDocuments/EquipmentBreakdown/Risk-topic2-BoilerandMachinery-insurance-Equipment-break-down.pdf;

${ }^{54}$ See, e.g., https://www.hsb.com/HSBGroup/Equipment_Breakdown_Basics.aspx; ; and http://www.nationwide.com/business-equipment-insurance-protection.jsp.

${ }_{55}^{55}$ See, e.g., http://www.wrg-ins.com/Commercial/EquipmentBreakdown.aspx.

${ }^{56}$ See, e.g., Howell v. Hartford Steam Boiler Inspection \& Ins. Co., 991 F.2d 795 (6th Cir. 1993); Hartford Steam Boiler Inspection \& Ins. Co. v. Pabst Brewing Co., 201 F. 617 (7th Cir. 1912); Riverbay Corp. v. Allendale Mut. Ins. Co., 1988 WL 52783 (S.D.N.Y. May 18, 1988); Philadelphia Mfrs. Mut. Ins. Co. v. Gulf Forge Co. 555 F. Supp. 519 (S.D. Tex. 1982); Cleveland v. Am. Motorists Ins. Co., 163 Ga. App. 748, 295 S.E.2d 190 (1982); Hartford Steam Boiler Inspection \& Ins. Co. v. White, 775 N.E.2d 1128 (Ind. Ct. App. 2002); Logestan v. Hartford Steam Boiler Inspection \& Ins. Co., 626 N.E.2d 829 (Ind. Ct. App. 1993); Van Winkle v. Am. Steam-Boiler Ins. Co., 52 N.J.L. 240, 19 A. 472 (Sup. Ct. 1890); Seay v. Travelers Indemnity Co., 730 S.W.2d 774 (Tex. Ct. App. 1987). In some cases, the issue turns on the interpretation of a statute. For example, in Cassell v. Babcock \& Wilcox Co., 186 A.D.2d 1000, 588 N.Y.S.2d 459 (1992), the court held that the insurer's boiler inspection was for the benefit of the worker victims, rather than the insurer, because the inspection was conducted to satisfy a state labor law requirement.

${ }^{57}$ See, e.g., GuideOne Mut. Ins. Co. v. Hunter, 286 Ga. App. 852, 650 S.E.2d 424 (2007); Hamill v. Pawtucket Mut. Ins. Co., 2005 VT 133, 179 Vt. 250, 892 A.2d 226 (2005).

${ }^{58}$ The one exception that I could find was Ayers v. Allstate Ins. Co., 62 A.D.3d 635, 878 N.Y.S.2d 190 (2009) (court holds that there is an issue of fact as to whether truck driver's economic losses were caused by his auto insurers negligent inspection of his car). 
in the way that workers' compensation or boiler and machinery insurers do. Rather, the type of direct regulation that homeowners' insurers provide tends to be very general and uncontroversial - the sort of clearly reasonable safety suggestions that, again, are supported by actuarial evidence and may be tied to premium discounts, but that is not likely to create a cause of action. The same goes for auto insurers. Giving premium discounts for safe driving, or for reducing the number of miles driven, is not a safety inspection or certification. It is not a certification that this activity is now safe. Whether there might be more tort cases brought against homeowners' and auto insurers if the duty were expanded is a different question.

Unlike with auto and homeowners' insurance, it is at least somewhat surprising that there are not more products liability insurance negligentinspection cases. In fact, we were able to find only one. In Deines v. Vemeer Manufacturing, ${ }^{59}$ the insured was a manufacturer of mechanical hay balers - a machine that cuts hay and then rolls into large bales. The case arose out of a products liability suit brought against the manufacturer and the insurer by an individual whose arm got caught in the baler's compression rollers and, as a result, later had to be amputated. The plaintiff alleged that his injury was caused by the unreasonably dangerous and defective nature of the design of the intake area of the baler, the operating manual, and the safety stickers on the side of the baler.

During the relevant period the insured had purchased product liability coverage from a large property-casualty insurance company. Part of the arrangement under that policy was that the insurer would inspect all of the equipment used by the insurer-manufacturer in making the balers. The insurer also reviewed the design of the baler itself as well as the warning labels and operating manuals that the manufacturer sent with the bailers to the purchasers. After these inspections were done, the insurer made suggestions for how the manufacturer-insured might enhance the safety of the baler. When making these inspections, the insurer deployed their loss prevention experts, who applied safety standards that had been adopted by various standard-setting industry groups-including the American National Standards Institute, the Occupational Safety and Health Administration, and the American Society of Agricultural Engineers. In addition to being a condition of coverage, the inspections were a selling point: part of the reason the insured manufacturer purchased products coverage with this particular insurer was to gain access to the insurer's advertised loss control service, including the onsite safety inspections. Indeed, the manufacturer-insured did not employ any safety engineers of its own, or conduct any safety inspections, because it was relying on those conducted by the insurer.

The court, when evaluating the plaintiff's tort claim against the insurer, applied each of the three prongs of the negligent undertaking rule from the Restatement quoted above. The court held, first, that there was no evidence that the insurer's inspection increased the risk beyond that which would have existed in the absence of the inspections. Hence, there was, as a matter of law, no liability under prong (a). However, the court then held that the insurer had in fact undertaken a duty owed to the plaintiff by the insured - that is, the duty

\footnotetext{
${ }^{59} 752$ F. Supp. 989 (Dist. Ct. Kansas 1990).
} 
of design reasonably safe products and the duty to warn of the risk of the product - and that the manufacturer-insured had relied on the insurer's inspections being reasonable. So there was liability, at least potentially, under prongs (b) and (c).

The court rejected the insurer's argument that the state's product liability statute, which limits liability in various ways, applied to the case, concluding that the statute was not intended to eliminate negligent inspection liability. In addition, the court held that the provision in the insurance policy that purported to eliminate any duty of reasonable care to third parties (including any duty that might arise out of the safety inspections) was void as against public policy.

The Dienes-type situation likely happens with some frequency: liability insurers who specialize in products liability coverage, employing products liability law experts as well as experts in product design, manufacturing, and labeling, providing product-specific recommendations to relatively small manufacturing companies who do not have the resources to maintain such expertise in house. Indeed, for the same reasons that workers' compensation and boiler/machinery insurers often provide rigorous safety inspections, one would expect that product liability insurers to do the same. And again, there are product liability insurers who do some of this, as evidenced by their web advertising and by anecdotal evidence from my own interviews with insurers. And yet, there are far fewer reported negligent inspection cases involving product liability insurance than there are involving workers' compensation or boiler/machinery liability insurance.

Some states, perhaps concerned that negligent inspection suits might result in higher premiums or withdrawal of coverage (or perhaps concerned that such suits will reduce insurer profits), have enacted statutes limiting the claims. Twenty states in fact have enacted statutes that appear to be designed to limit negligent inspection suits generally or to limit such suits against insurers in particular, or so the insurers argue. ${ }^{60}$ Some state courts have also sought to impose limits by interpreting existing statutes. For example, courts in a few jurisdictions have applied the workers' compensation statutes themselves, the ones that create the workers' compensation regime in a state, to provide tort immunity for workers' compensation insurers. ${ }^{61}$ Most courts, however, have

${ }^{60}$ See, e.g., ALA. CODE $§ 25-5-53$ (2014); ALASKa STAT. ANN. $\$ 23.30 .055$ (West 2014); ARIZ. REV. STAT. ANN. § 23-485 (2014); CAL. INS. CODE § 11759 (West 2014); Colo. Rev. StAT. ANN. § 8-41-104 (West 2014); Del. Code ANN. tit. 19, § 2304 (West 2014); Fla. STAT. ANN. § 440.11 (West 2014); GA. CODE ANN. § 34-9-11 (West 2014); IND. CODE ANN. §§ 22-3-2-6, 34-30-17-2 (West 2014); IOWA. CODE ANN. §§ 85.20, 88.6, 517.5 (West 2014); Me. Rev. Stat. tit. 14, § 167 (2013); Md. Code AnN., Lab. \& EMPL. §9-509 (West 2014); Mich. CoMP. LAWS ANN. §§ 418.131, 500.2925b (West 2014); N.Y. WORKERS' COMP. LAW $§ 11$ (McKinney 2014); R.I. GEN. LAWS ANN. §§ 27-7-2, 27-8-15, 28-36-7 (West 2014); TENN. CODE ANN. § 50-6-108 (West 2014); TEX. LAB. CODE ANN. § 408.001 (West 2013); VT. STAT. ANN. tit. 21, §§ 622, 624(h) (West 2014); WIS. STAT. ANN. § 895.475 (West 2013).

${ }^{61}$ See, e.g., Kifer v. Liberty Mut. Ins. Co., 777 F.2d 1325 (8th Cir. 1985); Johnson v. Am. Mut. Liab. Ins. Co., 559 F.2d 382 (5th Cir. 1977); Horne v. Sec. Mut. Cas. Co., 265 F. Supp. 379 (E.D. Ark. 1967); Barrette v. Travelers Ins. Co., 28 Conn. Supp. 1, 246 A.2d 102 (Super. Ct. 1968); Jadosh v. Goeringer, 442 Pa. 451, 275 A.2d 58 (1971). 
not so held. ${ }^{62}$ In any event, in the states in which a statute clearly protects insurers from negligent inspection liability, those statutes are enforced. These statutes can be seen as a type of insurance-company-specific Good Samaritan statute.

\section{Evaluating Alternative Tort Rules for Insurers as Private Regulators}

\section{The full coverage scenario: when disclaimers should be enforced}

This Part examines the regulatory or incentive effects on insurance companies and their insureds of the existing doctrine of negligent inspection, as well as the effects of several alternatives to current law. To provide a baseline for the analysis, observe that, if the insurer in question (the one doing the regulating) provides full coverage for the underlying loss, the optimal tort rule is probably the absence of any tort liability. In such a situation, which all I will call the "full coverage scenario," the insurer is contractually on the hook for the full amount of any such loss that arises. In other words, there are either no policy limits or the limits are high enough to cover any conceivable loss. In that scenario, at least in theory, there would be no regulatory benefit in providing injured victims with a tort cause of action against the insurer. The incentives created by the insurance contract itself should be sufficient to motivate the insurer to take all reasonable steps to help its insured reduce its risks, through inspections or standard setting. ${ }^{63}$ Thus, the optimal rule in full coverage scenario, from the perspective of the effect on incentives, would be one of no liability. Not coincidentally, a rule of no liability would also be desirable from the perspective of providing fair compensation, since the injured party, by assumption, is entitled to full compensation from the insurer. For these reasons, in a full coverage scenario, if the insurance policy contains a term disclaiming or waiving any tort duty to on the part of the insurer to the insured, a strong argument can be made that such a term should be enforced by the courts.

It is in the cases, and only in the cases, in which the policy issued by the regulating insurer is significantly less than the damages that can be recovered through a direct tort suit against the insurer for negligent inspection/regulation that tort law has any potential role. This divergence between insurance coverage and the potential negligent inspection remedy can happen in two general situations. First, there can be divergence when the insurance coverage in question does not cover the full losses that occur. This type of divergence can happen with first-party insurance coverage (e.g., boiler and machinery policies that do not cover personal injuries) or with liability insurance coverage (e.g., products liability policies that have low policy limits). Second, in the case of liability insurance in particular, there can be divergence

\footnotetext{
${ }^{62}$ See, e.g., Bryant v. Old Republic Ins. Co., 431 F.2d 1385 (6th Cir. 1970); Mays v. Liberty Mut. Ins. Co, 323 F.2d 174 (3d Cir. 1963); Stacy v. Aetna Cas. \& Sur. Co., 334 F. Supp. 1216 (N.D. Miss. 1971); Beasley v. MacDonald Eng'g Co. 287 Ala. 189, 249 So. 2d 844 (1971); Fabricius v. Montgomery Elevator Co., 148 Ga. App. 694, 252 S.E.2d 199 (1979).

${ }^{63}$ One qualification to this conclusion is that insurance contracts tend to be written on an annual basis. Therefore, the contractual cost-internalization would be limited to the risks of a single policy year.
} 
between the insurance coverage and the potential negligent inspection remedy when the underlying liability regime (the regime creating the liability for which insurance is purchased) has substantially limited remedies. The primary example of this type of divergence involves workplace injuries, where the workers' compensation regime provides a substantially smaller potential recovery than does a tort suit. The remainder of this Part addresses both types of divergence situations.

\section{Divergence type I: less-than-full insurance and judgment proof insureds}

The less-than-full insurance coverage situation provides the strongest case for imposing a tort-based duty on insurers. In the absence of such a tort duty, the insurer, in deciding how to regulate its insured (how rigorously to make its inspection, how detailed and comprehensive to make its safety recommendations, how insistent it should be about compliance with those recommendations), may be inclined to ignore any potential costs to third-party victims that exceed the amount of coverage contained in the insurance contract. Those additional costs, which are outside or above the coverage provided by the insurer, are simply not the insurer's contractual responsibility. As a result, there is an externality of sorts, or at least a potential externality, as the insurer externalizes those beyond-coverage costs to the insured.

To see this point, consider an example in which a property insurer provides first-party equipment breakdown coverage for an insured's boiler (for repair and replacement costs to the boiler in the event it breaks down) but no liability insurance coverage should the boiler explode. And for whatever reason, the insured has no separate policy providing liability coverage for such events - or liability coverage that expressly excludes harm resulting from exploding boilers. Assume also that there is a substantial difference between the optimal boiler inspection for the purpose of avoiding breakdown of the boiler and the optimal inspection for the purpose of avoiding injury to persons. The externality concern is that, in the absence of a legal rule forcing the insurer to take into account the uninsured liability risk of the insured, the insurer will have an incentive to do only the property-risk inspection, and not the personalinjury risk inspection, when in fact both types of inspections were called for. And the failure to conduct the personal-injury risk inspection may in fact lead to injuries to third parties. Similarly, imagine a product manufacturer that purchases a products liability insurance policy with very low policy limits. The liability insurer in that case might have an incentive to do only a cursory inspection, or none at all, given its relatively limited stake in the insured manufacturer's risk of liability; and that inadequate or nonexistent inspection could lead to a design flaw that results in numerous injuries or deaths. In both of these situations, the insurer is externalizing the uncovered losses to the insured - the party that purchased the boiler policy or the products liability policy.

A potential response to this conclusion is to suggest that there is in fact no externality. That is, so long as the losses are borne by the insurer and the insured, those parties - who are already in a contractual relationship with each other - can negotiate to the efficient, Coasean outcome. If it makes sense for the boiler insurer to do a personal-injury-type inspection of the boiler (as seems likely), then the insured can pay a somewhat higher premium to the insurer in 
return for that service. Likewise with the products liability example: Even if the products liability insurer is providing only limited coverage, if the insured is potentially liable for any product-related injuries arising out of the use of its products, and if the insurer is in a better position (information-wise) to provide the product risk assessment than the insured itself is, the insured can contract for such services. Moreover, the insureds in both examples will have an incentive to contract for such services. As a result, market forces-together with the underlying tort duty of the insureds - internalize any potential externality.

The externality in these cases returns, however, when the insured party is judgment proof. A potential tort defendant is judgment proof when its assets, including its liability insurance coverage, are insufficient to pay for the harm that can be caused by its activities. ${ }^{64}$ When a party is judgment proof, tort law-ex post sanctions generally - have limited usefulness as a regulatory tool, because the misbehaving party cannot be forced to pay an amount that exceeds the value of its assets. This is why some scholars argue that, when parties engaging in activities that pose risk to third parties are judgment proof, the preferred form of regulation is government-agency-based ex ante regulation. ${ }^{65}$ Still, there are reasons to prefer ex post sanctions, and tort law in particular, over ex ante government regulation. For example, ex post sanctions require significantly less information on the part of the regulator/court. ${ }^{66}$ To the extent such arguments in favor of ex post sanctions are persuasive, tort law has found ways to work around the judgment proof problem.

The doctrine of vicarious liability is one example. Vicarious liability holds one party liable for the torts of another under circumstances in which the first party either (a) is the cheapest cost avoider or, more importantly, (b) is one of the cheapest cost avoiders and has sufficient assets to be motivated by the threat of sanction. The classic example is employer liability for the torts of its employees committed within the scope of their employment. The idea is both that employers may be in the best position to prevent certain types of employee torts (in part because of information available only to the employer, and in part because the employer may have control over certain risky instrumentalitiessuch as heavy machinery-that are also available to employees) and that the employer, unlike the employee, is not judgment proof. ${ }^{67}$

Similar cheapest-cost-avoider plus judgment-proofness arguments have been deployed to justify a specialized form of vicarious liability known as "gatekeeper liability." ${ }^{\text {"68 }}$ With gatekeeper liability, the party held vicariously liable is, obviously, the keeper of the gate; the party whose approval or certification is required by the party whose actions directly caused the harm.

\footnotetext{
${ }^{64}$ Steven Shavell, The Judgment Proof Problem, 6 InTERnATIONAL ReV. L. \& ECON. 45 (1986).

${ }^{65}$ Steven Shavell, Liability for Harm Versus Regulation of Safety, 13 J. LEGAL STUD. 357 (1984).

${ }^{66} \mathrm{Id}$.

${ }^{67}$ Alan O. Sykes, The Economics of Vicarious Liability, 93 YALE L. J. 1231 (1984).

${ }^{68}$ Renier Kraakman, Gatekeepers: The Anatomy of a Third-Party Enforcement Strategy, 2 J. L. E. \& O. 53, 57 (1986) (justifying gatekeeper liability in part because of impossibility of imposing fines on "individuals or corporations more than the value of their net assets").
} 
Maybe the most well-known examples of gatekeeper liability arise in the context of corporate financial shenanigans. In such cases, by the time the harm is discovered, the parties who have been harmed (usually the parties who invested in the corporation without knowledge of the shenanigans) cannot recover for their losses from the defendant. Similarly, ex post sanctions against the offending corporation are ineffectual when the company has gone into bankruptcy. The Enron scandal is perhaps the most vivid example of this phenomenon, but the observation is more general: in such situations, a regime of regulation that seeks only to punish the offending corporation after the fact may not be enough.

For this reason, an argument can be made that the optimal regulator strategy in the context of corporate financial misbehavior includes, in addition to ex ante government regulation (SEC oversite), the extension of ex post liability beyond the corporation itself to the corporation's lawyers, accountants, lenders, and underwriters. These gatekeepers are all, in a sense, private regulators who have access to the relevant information regarding the corporation whose behavior needs to be regulated, private regulators whose stamps of approval are either legally or practically required for the regulated corporation to engage in the particular transactions that pose substantial risk to third parties (often to unsophisticated investors). ${ }^{69}$ Imposing a tort duty on these private regulators will encourage them to take reasonable care in determining whether to certify the books of the regulated corporations. That is the regulatory effect of gatekeeper liability.

All of these arguments-concerning vicarious liability generally and gatekeeper liability in particular-can be applied to insurers as private regulators of risk. In a sense, negligent inspection liability of insurers can be thought of as a specialized version of vicarious liability. Empowering injured third-party victims to bring tort actions against the insurance company who failed to take reasonable care when doing a workplace inspection or product safety evaluation could have the same sort of beneficial incentive effects that respondeat superior has in the employment context: insurers could be induced to take steps to prevent accidents that their insured does not have sufficient incentive to prevent. Imposing a tort duty on insurers could induce them to take into account costs that it might otherwise be ignored, as a result of the combination of inadequate coverage and a judgment proof insured.

Moreover, insurers sometimes do act as gatekeepers, at least to some extent. $^{70}$ The examples of home-mortgage lending and auto insurance were

${ }^{69}$ Id. See also Jay M. Feinman, Liability of Accountants for Negligent Auditing: Doctrine, Policy and Ideology, 31 FLA. ST. U. L. REV. 17 (2003); Assaf Hamdani, Gatekeeper Liability, 77 S. CAL. L. REV. 53 (2004).

${ }^{70}$ Others have emphasized the role of insurers as potential gatekeepers, especially in the context of corporate governance and financial disclosure. See, e.g., Joshua Ronen, PostEnron Reform: Financial Statement Insurance and GAAP Revisited, 8 STAN. J. L. BuS. \& FIN. 1 (2002); and Lawrence A. Cunningham, Choosing Gatekeepers: The Financial Statement Insurance Alternative to Auditor Liability, 52 U.C.L.A. L. REV. 413 (2004). In all of these proposals, however, the idea has been to make insurers only contractually liable, through financial insurance policies. So far as I know, no one has argued in favor of imposing tort liability on insurers who fail to take reasonable care in monitoring their insureds. 
mentioned in the introduction, but there are others. Businesses cannot legally operate, for example, without workers' compensation insurance coverage, which is mandatory in every state unless the business falls within certain statutory exceptions. Similarly, most businesses would find it practically impossible to function without other forms of property/casualty insurance. Many product manufacturers, for example, may find getting a loan to be very expensive or even impossible unless they can provide proof of adequate products liability coverage. Likewise, businesses that are heavily dependent on some piece of property - a building or a large, complex piece of machinerymay have difficulty getting credit at reasonable rates without proof of insurance against the possibility of breakdown. In such cases, when insurers function as gatekeepers, negligent inspection liability can be especially effective as means of internalizing costs externalized as a result of the judgment proof insured problem.

\section{Activity level effects}

When vicarious liability induces an employer to increase its monitoring and regulation of its employees' risky activities, or gatekeeper liability incentivizes a financial auditor to increase its scrutiny of a corporation's books, these can be understood as the "care-level effects" of such rules. There are also "activity-level effects." "When an employer, for example, is made subject to tort liability for the torts of its employees, the employer's costs are increased, in much the same way that its costs would be increased if a new excise tax were imposed. As a result, the employer may end up hiring fewer workers or paying lower wages, or perhaps replacing some of its workers with contract labor in hopes of avoiding liability. Similarly with gatekeeper liability, if corporate auditors, attorneys, and underwriters are made liable for the financial fraud of the corporations to whom they provide advice and whose integrity they certify, they (the gatekeepers) will raise their prices or cut back on the number of corporations they are prepared to certify or both. Precisely how the costs will be divided between the employers and employees or between the gatekeepers and gatekeepees depends on the relative elasticities of supply and demand in the relevant markets. But in any event, if the costs being imposed by vicarious liability are real costs that would otherwise be externalized, owing to judgment proof employees or agents generally, these activity level effects should tend towards efficiency.

The same sorts of beneficial activity-level effects could arise when insurers act as regulators or gatekeepers. Making the insurers subject to a potential tort suit for negligent inspection-just as exposing an accounting firm to the risk of liability for failure to perform a reasonable audit - is akin to an excise tax on insurers and can lead them to substantially increase their premiums, in some cases beyond a point that businesses are willing to pay. The insurer will be forced by the threat of negligent inspection suits to raise the price of their coverage to account for potential payouts far in excess of the stated policy limits. These negligent-inspection surtaxes are most likely to occur when the risks posed by the insured's business activities far outstrip the value of the company's assets. (Think of hotels with significant risk of fire,

${ }^{71}$ Steve Shavell was the first to clearly draw the distinction between care level and activity level effects. STEVEn SHAVELl, ECONOMIC ANALYsis OF ACCIDENT LAW (1987). 
workplaces where employees are systematically exposed to dangerous conditions, or product manufacturers whose products could harm large numbers of consumers.) In these situations, if insurance is effectively performing a gatekeeping function, some of these companies will be put out of business. That is, if they cannot persuade an insurer to provide them coverage at a premium they can afford - that the profits from their business can sustain - they will effectively be shut down. That result would be efficient, at least in theory.

Insurer withdrawal from regulation and the relative merit of carrots and sticks

A potential difficulty with using tort law to encourage insurers to regulate reasonably, especially the currently the rule, is the possibility that, facing the prospect of such liability, insurers will regulate in a way that is designed to avoid liability or, worse, will stop regulating altogether. As to the first possibility, recall that under current law insurers can be held liable in tort for negligent inspection only if the insured or some third party relies on those inspections being done reasonably; if there is no reliance, there is no cause of action. $^{72}$ In practical terms, what this means is that insurers will (and often do) insert language into their policies or promotional materials stating that any inspections or audits or other regulatory services are provided solely for the benefit of the insurer and are not to be relied upon by the insured or anyone else. Such statements amount to disclaimers of liability, which courts sometimes enforce, sometimes not.

The problem with this outcome, of course, is that, if insurance is to provide a useful regulatory function, there must be reliance. When insurers are better evaluators of an insured's risky activities than the insured is, reliance by the insured on the insurer's recommendations is exactly what we want. That is the point. Thus, permitting insurers to get off the hook by proving the absence of reliance has the effect of discouraging insurers from engaging in potentially beneficial private regulation - the type that is relied upon by the regulated party.

The more extreme response of insurers to the threat of negligent inspection suits is for insurers to stop inspecting, stop engaging in direct regulation, entirely. ${ }^{73}$ Again, under current law insurers can be held liable in tort for negligent inspection only if they "undertake" to provide inspection services. $^{74}$ Thus, if they simply refrain from doing any sort of safety inspections, or decline to provide any "loss control" risk-reduction counseling services, to their insureds, they can essentially eliminate their chance of being held liable in tort for negligent inspection. It is this sort of extreme withdrawal from regulation in response to the threat of liability that, according to anecdotal evidence, some insurers have been doing.

\footnotetext{
${ }^{72}$ Subsection (c) of Section 43 of the Restatement limits negligent inspection liability to situations in which "the person to whom the services are rendered, the third party, or another relies on the actor's exercising reasonable care in the undertaking."

${ }^{73}$ Indeed, this is the primary reason Professor Goldberg gives for his opposition to negligent inspection suits against insurers. Victor Goldberg, Tort Liability for Negligent Inspection by Insurers, in Research in Law and Economics: A Research Annual 76 (Richard O. Zerbe, editor) (1980).

Restatement (Third) Torts $§ 43$.
} 
One potential policy response to both types of insurer avoidance of their role as direct private regulator - their tendency to discourage reliance on their recommendations or to refrain from regulating at all-would be for more states to adopt what I have called insurer Good Samaritan statutes: laws that immunize insurance companies from lawsuits. Such laws, by eliminating insurer liability, create a legal environment in which insurers would have freedom to engage in aggressive direct regulation of their insureds' behavior, if that is called for, without fear of incurring tort liability far in excess of their policy limits. ${ }^{75}$ These statutes are obviously analogous to the better known Good Samaritan statutes in many states that protect certain individuals (usually limited to off-duty trained personnel, such as doctors and nurses) who voluntarily undertake to rescue those in imminent peril. ${ }^{76}$ Good Samaritan statutes generally, and insurer Good Samaritan statutes in particular, are a type of "carrot" approach to encouraging rescue: a positive reward to rescuers-a subsidy of sorts. ${ }^{77}$

The limitation of this particular carrot approach, however, is again the problem of less-than-full coverage. That is, with the threat of liability removed, it is true that insurers would no longer have an incentive to refrain from regulating their insureds or an incentive to discourage reliance on their recommendations - which amounts to the same thing. Rather, insurers would have an unambiguous financial incentive to regulate, but their incentive would again be capped by the limits of their coverage, the amount that the insurer has on the hook if the insured suffers a loss. For this reason, whether the adoption of an insurer Good Samaritan statute would on balance have beneficial incentive effects on insurer behavior would depend on a comparison of (a) the efficiency gains from those insurers who are induced by the statutory protection to engage in some useful regulation of their insureds by the elimination of the threat of liability with (b) the efficiency loss from those insurers who would have regulated in any event but who now, with the removal of the threat of liability, will regulate less effectively on account of the divergence between policy limits and amounts at risk of loss- the externality problem discussed above.

\footnotetext{
${ }^{75}$ The statute in Maine for example reads as follows: "The furnishing of, or failure to furnish, insurance inspection services related to, in connection with or incidental to the issuance or renewal of a policy of property or casualty insurance shall not subject the insurer, its agents, employees or service contractors to liability for damages from injury, death or loss occurring as a result of any act or omission by any person in the course of such services.” ME. REV. STAT. TIT. $14 \S 167$ (1982). Another example is from California, where the state insurance law places strict limits on negligent inspection lawsuits. Section 11759 of the California Insurance Code states that "licensed rating organizations and their officers and employees shall not be liable for injury or death or other damage caused or alleged to have been caused by their failure to inspect, or negligent or incomplete inspection of, an employer's location, plant or operation for classification or rating purposes.” CAL. INS. CODE $\S 11759$ (West).

${ }^{76}$ GOLDBERG, SEBOK \& ZIPURSKY, TORT LAW: RESPONSIBILITIES AND REDRESS 83-88 (3d. ed. 2012).

77 Saul Levmore, Waiting for Rescue: An Essay on the Evolution and Incentive Structure of the Law of Affirmative Obligations, 72 VA. L. REV. 879 (1986) (coining the use of "carrot" and "stick" labels in this context).
} 
How these two factors balance out in the real world presents the quintessential "difficult empirical question." My own intuition is that, all things considered, factor (a) is probably larger than factor (b), which means the adoption of insurer Good Samaritan statutes would be a sensible recommendation. However, if we consider tweaking the standard insurer Good Samaritan statute, we might be able to achieve an even better outcome, in terms of the overall effect on incentives. Consider the possibility of adding one additional element to those statutes: make the insurer's freedom from tort liability contingent on a finding by a court (presumably upon a motion by an insured to dismiss a negligent inspection case brought against it) that the amount of insurance involved in the case was adequate to cover the risk posed by the insured. Such a contingency would give insurers an incentive to make sure that insureds are purchasing adequate coverage, which would push things closer to the full coverage situation described above, where tort law would not be necessary to encourage optimal direct regulation by insurers. This solution would of course present additional complexities, perhaps the most difficult being how to define "adequate" coverage. But that question could left either to the courts (in individual negligent inspection cases), to the insurance regulators (who could promulgate standards of adequate insurance), or to state legislatures.

A critic at this point might have the following complaint. If higher insurance policy limits is the ultimate goal of this reform proposal, why not simply propose that state legislatures impose insurance mandates in areas where they have not yet done so and increase the limits in areas where mandates already exist but are too low. Once those are adopted, we would be close to a full-coverage scenario, and the need to impose a tort duty on insurers to regulate would be eliminated. There is something to be said for this argument. Many scholars have suggested mandatory liability insurance as a response to the judgment proof problem generally. ${ }^{78}$ Likewise, broader use of, and more beefed up, insurance mandates could be a solution to this version of the judgment proof problem as well. However, expanding the use of legislative insurance mandates is likely to be politically unpopular; whereas, the sort of statute envisioned in the text is not quite as intrusive as an actual insurance mandate. Insurers could still opt not to provide full coverage and simply risk the possibility of a negligent inspection suit. Moreover, at least in those states that do not currently have any insurer Good Samaritan statute, the adoption of the modified form that I am suggesting could be seen as a compromise-a middle position between no liability limiting statute (the status quo) and a new liability limiting statute that encourage (but doesn't actually mandate) higher policy limits.

The alternative, and considerably more radical, policy response to insurers' reluctance to regulate - or their withdrawal from regulation, if that is happening - would be to eschew the (modified) carrot of (contingent) freedom from tort liability for the unambiguous stick: an affirmative duty to regulate. The idea would be to penalize those insurers who fail to regulate when they should by imposing on them a duty in tort to affirmatively engage in direct

\footnotetext{
${ }^{78}$ See, e.g., Shavell, The Judgment Proof Problem, supra note __; and Peter J. Jost, Limited Liability and the Requirement to Purchase Insurance, 16 INTERNATIONAL REV. L. \& ECON. 259 (1996).
} 
regulation of their insureds' behavior when doing so is reasonable. Such a duty to regulate would clearly be a departure from current law. Moreover, it would arguably be inconsistent with the approach the law has taken to affirmative obligations in other contexts. The most obvious example is the general noduty-to-rescue rule mentioned in the introduction. And the arguments that have been made in defense of that rule would apply as arguments against a duty to regulate rule here. For example, William Landes and Richard Posner have pointed out adopting an affirmative duty to rescue would encourage potential rescuers to avoid situations in which they might be called on to rescue. Picture off-duty doctors, nurses, and EMT workers avoiding swimming pools and public beaches. ${ }^{79}$

What is the analog in the insurance context? Insurance companies refusing to offer insurance coverage to certain insureds, for fear of being held liable in tort for failing to regulate every time there is a loss claim? That is, it is one realistic possibility. Some insurers may well decline coverage for some insureds. Other insurers, however, may continue to insure, but instead start to engage in active regulation to minimize their risks. Almost certainly insurers would respond by pricing their coverage to include the risk of a duty-toregulate lawsuit. Perhaps even more likely, insurers might both raise their prices and insist on higher policy limits; if they are going to be taking on the risk of being held liable for amounts beyond their existing policy limits anyway (under and affirmative duty to regulate), they might as well raise their policy limits and their prices. This change would again move us towards the fullcoverage scenario, where the negligent inspection tort suit would be rendered irrelevant.

Note also that imposing an affirmative obligation on insurers to regulate would not be totally without precedent. Recall the various "special relationship" exceptions to the general no-duty-to-rescue rule mentioned above. The idea of imposing this obligation on insurers would be to treat the insurer/insured relationship as being more akin to the business-premisesowner/business-guest relationship, the employer/employee relationship, or even the teacher/student relationship. ${ }^{80}$ A primary reason for these special relationship exceptions is that they provide a way to draw administrable lines in deciding who is potentially liable under this affirmative duty to help. That is, whereas it would be quite burdensome, on the affected parties and on the judicial system, to have an unrestricted affirmative duty to rescue, a rule that applies only to parties in certain categories of special relationships is narrower, less burdensome generally, and easier for courts to apply. Imposing an affirmative duty on insurers to provide regulatory advice to their insureds when it is reasonable to do so could be seen as another example of a special relationship.

But let's not kid ourselves. Imposing a new affirmative tort duty on insurers to engage in "reasonable inspections" when it is "reasonable to do so" would be highly controversial. What's more, it would, if it works, produce a result not entirely different from the modified (adequate-policy-limitcontingent) version of the insurer Good Samaritan statute that I suggested

\footnotetext{
${ }^{79}$ Landes \& Posner, Salvors, Finders, Good Samaritans, and Other Rescuers: An Economic Study of Altruism, 7 J. LEGAL STUD. 83 (1978).

${ }^{80}$ GOLBERG, SEBOK \& ZIPURSKY, supra note _ , at _.
} 
above. Both reforms would tend to push up the amount of coverage offered by insurers, thus helping to align the inspection/regulation incentives of insurers with those of society. The latter reform, however, would have two big advantages over the former. First, it would be less of a departure from current law, and, as a political matter, less of an apparent imposition of costs on insurers, for the reasons described above. Second, it would less direct regulation by courts of the business of insurance than does the duty to regulate. That is, if the insurer modified Good Samaritan statute works as planned, there would rarely be a need for courts to hear negligent inspection cases against insurers, assuming insurers write policies with adequate coverage, since the insurers would be immune. By contrast, under the affirmative duty to regulate approach, courts would continually be called on to second guess insurer's regulatory judgments - both whether to regulate and how-a task for which courts are not necessarily well suited. ${ }^{81}$ This is of course not a critique unique to tort suits against insurance companies for what amounts to negligent risk regulation. To the contrary, negligent-based tort cause of action that involves complex and technical issues of engineering and science present difficulties for courts. (Risk-utility analysis in product design defect cases are similarly difficult for courts.) The point is that the critique would be less applicable to the insurer Good Samaritan statute alternative.

\section{Divergence type II: the workers' compensation example}

I noted above that negligent inspection liability against insurers only makes sense, even potentially, as a regulatory tool in situations in which the insurer provides less than full coverage. That is, there must be a divergence, a gap, between the insurance coverage and the potential negligent inspection remedy. Until now, I have been discussing situations in which the gap arises because the insured for market reasons, or for reasons having to do with being judgment proof, purchases less full coverage for the losses its activity might cause. There is another source of coverage gap, which applies primarily to workers' compensation insurance but could apply to any situation where the underlying liability regime (the regime creating the liability for which insurance is purchased) provides remedies for injured victims that are substantially less than those available through a tort claim.

Consider the workers' compensation example. When a worker is injured on the job, she does not have a traditional tort claim against her employer, even if she can prove that his employer's negligence caused his injury. As a result of state workers' compensation statutes, many of which were enacted in the early part of the Twentieth Century, a worker's remedies are limited to partial recovery for medical expenses, lost income, and vocational rehabilitation cost, all of which may be subject to a cumulative cap. ${ }^{82}$ Note, then, that under a typical workers' compensation regime today (perhaps under

\footnotetext{
${ }^{81}$ This is of course not a critique unique to tort suits against insurance companies for what amounts to negligent risk regulation. To the contrary, negligent-based tort cause of action that involves complex and technical issues of engineering and science present difficulties for courts. (Risk-utility analysis in product design defect cases are similarly difficult for courts.) The point is that the critique would be less applicable to the insurer Good Samaritan statute alternative.

${ }^{82}$ Price V. Fishback \& Shawn Everett Kantor, A Prelude to the Welfare STATE: THE ORIGINS OF WORKERS' COMPENSATION (2000).
} 
all of them), neither pain-and-suffering damages nor punitive damages may be recovered by the injured worker. ${ }^{83}$ Contrast that outcome with the traditional tort remedies available in non-workplace settings. Those remedies include unlimited recovery for compensatory damages, including pecuniary (medical expenses, lost income, and the like) as well as nonpecuniary damages (pain and suffering) and, at least potentially, punitive damages.

Given this divergence, a proponent of tort liability as a regulatory tool might initially argue that the negligent inspection suit provides an especially useful regulatory tool for improving workplace safety. Since workers' compensation remedies do not include some of the real costs associated with workplace injuries (yes, pain and suffering is a real cost), the threat of workers' compensation damages does not give employers sufficient incentive to maintain workplace safety. Imposing tort liability on workers' compensation insurers when they fail to do a reasonably effective workplace inspection, which results in an injury to a worker, serves a useful cost-internalizing function.

Critics of tort law as a mode of regulation would have a number of familiar responses to this line of argument. Jury awards in tort cases, especially pain-and-suffering damage awards, are inaccurate and wildly inconsistent, or so they would say. They would also point out that people do not generally purchase first-party insurance coverage for purely non-economic losses. Why is that fact relevant? If true, it would mean that when tort law forces insurers to raise their premiums to cover the possibility that they might be held liable, through a negligent inspection lawsuit, for the pain-and-suffering damages of some unfortunate person, the law will be making insureds pay for a type of insurance that they do not want. Finally, these critics would likely note that the main point of workers' compensation laws was to eliminate the inconsistencies and excesses of tort liability (including pain-and-suffering damages) in exchange for the elimination of several defenses that employers had at in common tort cases, such as the fellow servant rule. To permit injured third parties to recover pain-and-suffering damages from insurers for breach of the duty to provide reasonable inspections, when the same injured parties cannot sue the insured-employer directly for the same damages, undermines the political and pragmatic compromise represented by the workers' compensation law reforms. ${ }^{84}$

The problem with the argument is that it gives greater scope to the workers' compensation compromise than may be warranted. Although workers' compensation laws were intended to limit remedies that employees have against their employers for workplace injuries, they were not intended to limit employees' remedies against everyone. For example, if an employee is injured in the workplace by a product, some large piece of equipment or machinery, say, that employee can bring a products liability claim or a negligence claim against the product manufacturer in addition to their workers' compensation claim. And the damages available in the products liability case, of course, in most jurisdictions still include pain-and-suffering damages. What's more, this side-by-side coexistence - of the traditional tort remedies against product manufacturers and the more limited remedies against the

\footnotetext{
${ }^{83}$ PETER M. LENCIS, WORKERS COMPENSATION: A REFERENCE AND GUIDE (1998).

${ }^{84}$ See generally FISHBACK \& KANTOR, supra note _ (discussing political compromise reached between unions and employers).
} 
employer-is not considered problematic, at least as a legal matter. Product manufacturers were clearly not a part of the big bargain that produced the workers' compensation regime, and they are not protected by workers' compensation statutes. ${ }^{85}$ Likewise, workers' compensation insurers were not part of that grand bargain. That is, at the time the workers' compensation statutes were originally enacted, although the lawmakers contemplated that workers' compensation liability insurers would provide workers' compensation policies to employers to cover the damages that employers would be required to pay, there is no evidence that they intended to limit independent tort remedies against workers' compensation insurers who fail to take reasonable care when providing services to the insureds. Frankly, lawmakers were probably not thinking about that particular issue. As a result, it is no surprise that most, though not all, courts that have addressed the question have held that workers' compensation statutes themselves, the ones that created the workers' compensation regimes, do not themselves immunize workers' compensation insurers from negligent inspection liability. ${ }^{86}$

Whether negligent inspection suits should be available against workers' compensation insurers, then, turns not on factors specific to workers' compensation coverage, but rather on the issues discussed above in connection with other types of insurance: the extent to which the presence of such suits is likely to discourage insurers from inspecting at all and whether that effect would be greater or less than the effect of the rule on the quality of the inspections. Unlike with other types of insurance, where the problem boiled down to insufficient coverage and the solution was to find a way to encourage insurers to offer full coverage, with workers' compensation the amount of liability and the amount of insurance coverage are both determined by statute and regulation. Therefore, the only way to increase the coverage, and thereby to eliminate the need and motivation for the negligent inspection suits, would be to reform workers' compensation regimes generally to provide greater damages, including pain-and-suffering damages. Or we go do the reverse and reform tort law to be more like workers' comp. Either approach would likely eliminate the need for what amounts to vicarious liability suits against insurers.

\section{Conclusion}

Insurers have access to information that puts them in the ideal position to be effective private regulators of their insureds' risky activities. And they have exceptionally effective regulatory tools. Nothing motivates someone to change their behavior like a financial reward, in the form of a premium discount. And when insurers control access to certain domains of the economy - either because of legal or practical requirements - the ability to

\footnotetext{
${ }^{85}$ Jonathan M. Weisgall, Product Liability in the Workplace: The Effect of Workers' Compensation on the Rights and Liabilities of Third Parties, 1977 WIS. L. REV. 1035 (1977).

${ }^{86}$ Contrast Beasley v. MacDonald Eng'g Co., 287 Ala. 189, 249 So. 2d 844 (1971) (holding that the state's workers' compensation law, which prohibits lawsuits against employers, did not apply to negligent inspection suits against workers' compensation insurers, even though the term "employer" was defined in certain situations to include insurers) McHargue v. Stokes Div. of Pennwalt Corp., 649 F. Supp. 1388 (D. Colo. 1986) (holding that the Colorado workers' compensation statute immunizes workers' comp insurers from liability for negligent inspection).
} 
withhold coverage can induce insureds to follow the insurer's recommendation for how to reduce potential losses. Moreover, because insurers are bonded to the interests of their insureds, as a result of their contractual obligation to pay the insured's claims, insurers are motivated to find ways to minimize insured losses. For all these reasons, if tort law, in particular if the existence of negligent inspection lawsuits by insureds against insurers, is discouraging insurers from engaging in some types of direct regulation of their insureds' behavior, perhaps some insurers need some additional encouragement. This Article has argued that a modified carrot approach to providing such encouragement, where insurers are given immunity from tort liability if they demonstrate adequate coverage amounts, might be superior to a more radical stick approach, which would take the form of an affirmative duty to regulate. 